Jurnal Riset Kesehatan

http://ejournal.poltekkes-smg.ac.id/ojs/index.php/jrk

\title{
HUBUNGAN ANTARA INDEKS MASSA TUBUH (IMT), ASUPAN ZAT GIZI DAN RIWAYAT REPRODUKSI DENGAN KEPADATAN MINERAL TULANG PADA WANITA PRE MENOPAUSE
}

\author{
Ana Yuliah Rahmawati*) \\ Jurusan Gizi ; Poltekkes Kemenkes Semarang \\ Jl. Wolter Monginsidi ; Pedurungan ; Semarang
}

\begin{abstract}
Abstrak
Jumlah wanita pre menopause yang menderita osteoporosis belum diketahui secara pasti tetapi risiko osteoporosis pada wanita cukup tinggi. Menganalisis hubungan antara Indeks Massa Tubuh (IMT), asupan zat gizi dan riwayat reproduksi dengan kepadatan mineral tulang pada wanita pre menopause Rancangan penelitian crosssectional, berlokasi di kecamatan Genuk, Semarang. Pengambilan sampel dilakukan dengan teknik cluster random sampling dan subyek penelitian sebanyak 60 orang. IMT dihitung berdasarkan berat badan $(\mathrm{kg}) /$ tinggi badan $(\mathrm{m})^{2}$, asupan zat gizi diukur dengan kuesioner food frequency semi kuantitatif, riwayat reproduksi dengan kuesioner dan kepadatan mineral tulang dengan ultra sound bone densitometry. MT subyek penelitian 43,3\% kategori normal. Tingkat kecukupan vitamin A,C,D; mineral $\mathrm{Ca}$ dan $\mathrm{Fe}$ tergolong rendah,sedangkan protein dan $\mathrm{P}$ tergolong cukup. Rerata usia pertama kali menstruasi 12,7 tahun $+1,33$, rerata paritas 2,2 kali $+0,79$, rerata usia pertama kali hamil 23,9 tahun $+3,62$ dan rerata Tama menyusui 19,3 bulan $\pm 7,36$. Rerata t-score Kepadatan mineral tulang $-1,31 \pm 1,17$ dan sebagian besar subyek penelitian (50\%) termasuk osteopenia, $30 \%$ normal dan $20 \%$ osteoporosis. Semua variabel independen tidak ada yang berhubungan dengan t-score kepadatan mineral tulang, akan tetapi ada kecenderungan positif pada IMT; asupan protein; vitamin A, D;mineral $\mathrm{Ca}, \mathrm{P}, \mathrm{Fe}$; usia pertama hamil dan lama menyusui. Kecenderungan negatif pada vitamin $\mathrm{C}$, menarche dan paritas. IMT, asupan zat gizi dan riwayat reproduksi tidak berhubungan dengan kepadatan mineral tulang, hanya umur yang bekorelasi negatif dengan kepadatan mineral tulang.
\end{abstract}

Kata kunci: IMT; asupan zat gizi ; riwayat reproduksi; kepadatan mineral tulang; wanita pre menopause

\begin{abstract}
[CORRELATION OF BODY MASS INDEX (BMI), NUTRIRIONS INTAKE, REPRODUCTIVE HISTORY AND BONE MINERAL DENSITY IN PRE MENOPAUSE WOMEN] There were no available data related to the prevalence of osteoporosis among the pre menopause women, while the women have high risk in osteoporosis diseases. To analyze correlation between Body Mass Index (BMI), intake nutrition, reproductive history and bone mineral density (BMD) in pre menopause women. The study was the cross sectional and. was done in Genuk, Semarang. Sixty subjects were choosen by cluster random sampling. Data collection included BMI that was computed as weight $(\mathrm{kg}) /$ height $(\mathrm{m})^{2}$, nutrition intake measured with semi quantitative food frequency questionnaire, reproductive history with questionnaire and BMD with ultrasound bone densitometry. $43.3 \%$ of subject had BMI categorized as normal. The adequacy of vitamin A, vitamin C, vitamin D, Calcium and Iron was classified as low, while Protein and Phosphor was sufficient. The majority of subjects had first menarche at age of 12.7 years \pm 1.33 , the mean of parity was 2.2 times \pm 0.79 , and for age at first pregnant was 23.9 years $\pm 3 . \overline{6} 2$, and for duration of breastfeeding $\overline{19} .3$ month \pm 7.36. The mean $\mathrm{t}$-score of BMD was $-\overline{1} .31 \pm 1.17$ and $\mathrm{t}$-score was classified as Osteopenia, normal and osteoporosis. The percentage was $50 \%, 30 \%$ and $20 \%$ respectively. The result showed that there was positive correlation between BMI, Intake of protein,
\end{abstract}

*) Penulis Korespondensi.

E-mail: ana_birawanto2010@yahoo.comＣopyright @ C 2016, Jurnal Riset Kesehatan, ISSN 2252-5068 
Vitamin A, Vitamin D, Calcium, Phosphor, Iron, the age of first pregnant, duration of breastfeeding and BMD while Vitamin $\mathrm{C}$, the first menarche and parity had negative correlation. However the hypothesis analyses were not significant. BMI, nutrition intake and reproductive history no correlation with bone mineral density, only age was negatively correlated.

Keywords: BMI ; nutritions intake ; reproductive histor ; bone mineral density ; pre menopause women

\section{Pendahuluan}

Dismenore merupakan kejadian yang paling banyak terjadi dalam 3 tahun pertama setelah menarke (dismenore primer), walaupun kejadian tersebut dapat terjadi pada masa akhir kehidupan reproduksi wanita (dismenore sekunder) (Varney, 2006). Di Indonesia angka kejadian dismenore sebesar $64.25 \%$ yang terdiri dari $54,89 \%$ dismenore primer dan 9,36\% dismenore sekunder (Info sehat, 2008). Di Surabaya di dapatkan 1,07\%-1,31\% dari jumlah penderita dismenore datang ke bagian kebidanan

Masyarakat di Indonesia telah lama menggunakan bahan-bahan alami untuk mengatasi berbagai masalah kesehatan. Misalnya, dalam mengatasi sakit pada saat menstruasi (dismenore), para perempuan di Indonesia memanfaatkan kunyit dan asam yang dibuat menjadi minuman.

Bahan-bahan alam lain yang dapat digunakan untuk mengatasi dismenore, yaitu wortel. Namun belum banyak yang menggunakan wortel untuk mengatasi nyeri haid. Beta karoten yang terkandung dalam wortel mempunyai efek analgetik jika diberikan dalam dosis tertentu. Tujuan penelitian ingin mengetahui pengaruh pemberian air perasan wortel terhadap berba gai tingkat nyeri dismenore pada mahasiswa.

\section{Metode}

Rancangan penelitian yaitu cross-sectional. Lokasi penelitian dilakukan di wilayah kecamatan Genuk kota Semarang. Pemilihan sampel dilakukan secara Cluster random sampling. Kriteria inklusi sampel/subyek penelitian adalah : usia di atas umur 35 tahun dan belum menopause, berdomisili minimal 6 (enam) bulan di kecamatan Genuk kota Semarang. Kriteria eksklusinya : sedang hamil/menyusui, riwayat fraktur dalam keluarga; menderita penyakit diare kronis, diabetes mellitus, ginjal, hati dan anoreksia nervosa; mengkonsumsi alkohol, kopi, minuman soda yang berlebihan, obat-obatan golongan steroid, feno barbital dan fenitonin; memakai KB pil, suntik atau implant.

Kepadatan mineral tulang/Bone Mineral Density (BMD) diukur 2 kali dengan mengunakan alat Quantitative Ultrasound Bone Densitometry. Bagian tulang yang diukur adalah tulang kalkaneus/ bagian tumit kaki.

Asupan zat gizi yaitu protein, vitamin (A, C dan D), mineral (kalsium, fosfor, zat besi) diperoleh melalui wawancara dengan Food Frequency Questionnaire/FFQ semi kuantitatif dan diolah dengan software Nutrisurve.

IMT dikategorikan dalam 5 kategori yaitu kurus (IMT<18,5), normal (IMT 18,5-23)23), overweight (IMT 23-25), obese I(25-30), obese II (IMT>30). Asupan zat gizi dikategorikan menjadi 3 kategori yaitu asupan lebih jika > $110 \%$, cukup $80-110 \%$. Rendah $<80 \%$. Kepadatan mineral tulang berdasarkan t-score dikategorikan dalam 3 kategori yaitu normal $<-1$ SD, osteopenia -1 SD sampai $-2,5$ dan osteoporosis $>2,5$.

Analisis data dilakukan dengan program komputer. Uji statistik yang digunakan yaitu uji korelasi r pearson dan uji rank sperman.

\section{Hasil dan Pembahasan}

Rerata umur subyek pada penelitian adalah 39,67 tahun $\pm 3,8$ dengan usia minimal 35 tahun dan usia maksimal 49 tahun. Bertambahnya umur baik laki laki maupun perempuan akan mengalami penurunan enzim laktose yang diperlukan untuk mencerna susu sehingga hanya sedikit kalsium yang terserap. ${ }^{10,11}$ Pengaruh umur yang berkorelasi negatif dengan kepadatan mineral tulang berkaitan dengan proses penuaan. Akibat proses penuaan terjadi penurunan kemampuan fungsional sel sel tulang dan berakibat pembentukan tulang berkurang dibandingkan resorpsi. ${ }^{12}$

Status gizi subyek penelitian berdasarkan nilai IMT sebagian besar $(43,3 \%)$ termasuk kategori normal. Semakin besar IMT seseorang semakin tinggi kepadatan mineral tulang mereka. Analisis beberapa penelitian di Canada, USA, Eropa, Australia dan Jepang membuktikan resiko osteoporosis meningkat sehubungan 
dengan IMT yang kurang pada 22 orang di kalangan pria dan juga wanita. ${ }^{10}$

Tingkat kecukupan protein subyek penelitian sebesar $51,7 \%$ dengan kategori cukup dan hanya $15 \%$ dengan kategori kurang, akan tetapi bila dilihat dari reratanya asupan protein nabati lebih besar dibandingkan protein hewani. Peningkatan konsumsi protein nabati dan penurunan asupan protrein hewani akan menurunkan kerapuhan tulang dan risiko kerusakan tulang panggul. Hasil tersebut masih harus diperkuat dengan hasil penelitian prospektif lainnya dan diuji secara percobaan teracak. ${ }^{13}$

Tingkat kecukupan vitamin A subyek penelitian sebagian besar $(63,3 \%)$ dengan kategori rendah, yang cukup hanya sebesar $20 \%$. Tingkat kecukupan vitamin A yang rendah akan menyebabkan pertumbuhan tulang terganggu akan tetapi kelebihan vitamin A dapat mempercepat resopsi tulang, kerapuhan tulang dan terjadinya fraktur tulang. ${ }^{4}$

Tingkat kecukupan vitamin C subyek penelitian sebagian besar $(41,7 \%)$ dengan kategori rendah. Defisiensi vitamin $\mathrm{C}$ berkaitan dengan perkembangan tulang yang tidak normal. Pada proses pembentukan tulang, vitamin C berfungsi untuk stabilitas kolagen dan pembentukan tulang. Defisiensi vitamin $C$ dihubungkan dengan terganggunya hubungan antar jaringan tubuh. ${ }^{15}$

Tingkat kecukupan vitamin D subyek penelitian sebagian besar (63,3\%) dengan kategori rendah. Vitamin D bisa diperoleh dari paparan sinar matahari maupun dari asupan makanan sehari hari. Walaupun asupan subyek penelitian sebagian besar rendah, akan tetapi iklim tropis di Indonesia memungkinkan kecukupan vitamin D cukup yang bisa didapatkan dari paparan sinar matahari.

Tingkat kecukupan kalsium subyek penelitian sebagian besar $(96,7 \%)$ dengan kategori rendah, yang cukup hanya sebesar $3,3 \%$. Asupan kalsium mempengaruhi pencapaian massa tulang puncak dan juga dengan baik mampu untuk mempertahankan kalsium kerangka sepanjang kehidupan. Homeostatis kalsium negatif disebabkan oleh kurangnya asupan makanan, penyerapan yang lemah atau pengeluaran yang berlebihan yang mengakibatkan kehilangan kalsium dari tulang dan selanjutnya dapat meningkatkan kejadian patah tulang. ${ }^{14}$

Tingkat kecukupan fosfor subyek penelitian sebagian besar $(43,3 \%)$ dengan kategori cukup dan yang lebih sebesar $31.7 \%$. Walaupun fosfor adalah zat gizi yang penting, perlu dipertimbangkan bahwa jumlah yang berlebihan dapat merusak tulang. Sebagai contoh, suatu peningkatan konsumsi makanan yang mengandung fosfor akan meningkatkan konsentrasi fosfor serum dan akan menghasilkan suatu penurunan sementara kalsium terionisasi dalam serum mengakibatkan peningkatan sekresi hormon paratiroid yang potensial menyerap tulang. Fungsi utama hormon paratiroid adalah untuk mencegah hipokalsemia dengan meningkatkan penyerapan kalsium pada tulang. ${ }^{16}$ Tingkat kecukupan zat besi subyek penelitian sebagian besar $(43,3 \%)$ dengan kategori rendah.

Riwayat reproduksi merupakan kegiatan reproduksi yang dialami wanita. Riwayat reproduksi yang diteliti adalah usia menarche, paritas, usia pertama kali hamil dan rata rata lama menyusui. Variabel ini penting untuk diteliti karena masa reproduksi berkaitan dengan penggunaan kalsium dalam tubuh. Penggunaan kalsium pada masa reproduksi terutama pada masa hamil dan menyusui sangat besar. Masa tersebut bagi seorang ibu harus berbagi kalsium dan zat gizi lainnya kepada janin yang dikandungnya dan anak yang disusuinya.

Sebagian besar subyek penelitian (50\%) termasuk dalam kategori osteopenia, 30\% dalam kategori normal dan 20\% termasuk dalam kategori osteoporosis. Pengukuran kepadatan mineral tulang dinyatakan dalam nilai t-score. Berdasarkan hasil penelitian, walaupun subyek penelitian belum menopause akan tetapi persentase yang termasuk kategori osteoporosis mencapai $20 \%$. Keadaan ini bisa disebabkan massa tulang puncak dari subyek penelitian tidak terlalu besar sehingga walaupun belum menopause sudah termasuk dalam kategori osteoporosis.

Hasil penelitian menunjukkan ada hubungan negatif yang signifikan antara umur dengan kepadatan mineral tulang yang ditunjukkan dengan nilai $p=0,002$ dan $r=0,388$. Hasil penelitian sejalan dengan penelitian Mulyono ${ }^{17}$ bahwa umur berkorelasi negatif dengan kepadatan mineral tulang pada wanita pasca menopause di Jakarta. Hasil yang sama juga dijelaskan oleh Unni et al ${ }^{18}$ pada wanita di atas 40 tahun di India. Umur sebagai salah satu faktor yang berkorelasi negatif dengan kepadatan mineral tulang berkaitan dengan proses penuaan. Pertambahan usia 
mengakibatkan pembentukan tulang berkurang dibandingkan resorpsi. Berkurangnya kemampuan osteoblas membentuk tulang baru dapat disebabkan oleh kerusakan selular atau berkurangnya faktor faktor pertumbuhan lokal yang diperlukan untuk memacu pertumbuhan sel tulang baru. ${ }^{12}$ Proses resorpsi melebihi formasi setelah usia 30-45 tahun, ketidakseimbangan ini disebabkan peningkatan osteoklas dan penurunan osteoblas.

Hasil penelitian menunjukkan tidak ada hubungan antara IMT dengan kepadatan mineral tulang yang ditunjukkan dengan nilai $p=$ 0,732 dan $r=0,047$. Hasil penelitian berbeda dengan penelitian Nurchasanah ${ }^{19}$ dan Kosnayani20 subyek penelitian mereka wanita pasca menopause sedangkan pada penelitian ini wanita pre menopause. Hasil penelitian yang tidak signifikan bisa disebabkan jumlah subyek penelitian yang tidak terlalu besar (60 orang). Subyek penelitian juga wanita pre menopause yang penurunan kadar estrogennya belum terlalu besar sehingga IMT tidak berpengaruh signifikan terhadap kepadatan tulang. IMT merupakan prediktor ostoporosis dan berkaitan dengan peningkatan resiko fraktur pada wanita umur 40 - 59 tahun. ${ }^{21}$ Penelitian Unni et al 18 juga menunjukkan hubungan yang tidak signifikan antara IMT dengan kepadatan mineral tulang pada wanita India di atas umur 40 tahun.

Secara umum IMT yang lebih besar memberi beban mekanis yang besar pada tulang dan meningkatnya IMT memberikan beban yang semakin besar. Meningkatnya IMT akan meningkatkan jaringan adiposa yang merupakan sumber penting dari produksi estrogen pada wanita menopause. Estrogen diketahui sebagai penghambat resorpsi tulang oleh osteoklas dan akhirnya meningkatkan massa tulang karena kemungkinan peningkatan aktifitas osteoblas. ${ }^{22}$ Semakin banyak jaringan lemak yang dimiliki maka akan semakin banyak hormon estrogen yang diproduksi dan adanya penumpukan jaringan lunak dapat melindungi tubuh dari trauma dan patah tulang.

Hasil penelitian menunjukkan tidak ada hubungan yang bermakna antara total protein, protein hewani, protein nabati dan rasio protein hewani dan nabati dengan nilai kepadatan mineral tulang. Sellmeyer et al 13 menyatakan antara protein hewani dan nabati memberi efek yang berbeda dalam metabolis me tulang. Nilai $p$ pada protein nabati lebih mendekati 0,05 dari pada protein hewani, artinya protein nabati lebih mempengaruhi kepadatan mineral tulang dari pada protein hewani. Asupan protein nabati subyek juga lebih tinggi dari pada protein hewani dan memberi efek basa yang memperlambat laju perusakan tulang oleh osteoklas. Kersteter et al 23 menyatakan diet rendah protein selama 4 hari pada wanita yang sehat meningkatkan 1,5-3 \% konsentrasi hormon parathyroid dan 1,25 dihydroxyvitamin $\mathrm{D}_{3}$ dan menurunkan ekskresi kalsium urin.

Hasil penelitian sama dengan penelitian Nurchasanah ${ }^{19}$ bahwa tidak ada hubungan yang bermakna antara protein total dengan kepadatan mineral tulang akan tetapi menunjukkan kecenderungan yang positif. Hasil yang tidak signifikan bisa disebabkan oleh asupan kalsium yang tidak adekuat karena sebagian besar $(96,7 \%)$ subyek penelitian asupan kalsiumnya rendah. Penelitian sebelumnya oleh Mazess \& Barden 24 juga menyatakan ada hubungan antara asupan protein dengan kepadatan mineral tulang jika asupan kalsiumnya adekuat.

Hasil pada penelitian tidak ada hubungan yang bermakna antara asupan vita min A dengan kepadatan mineral tulang yang ditunjukkan oleh nilai $p=0,911$ dan nilai $r=-0,015$. Hasil penelitian sama dengan penelitian Nurchasanah ${ }^{19}$ dan Ramayulis ${ }^{25}$ bahwa tidak ada hubungan antara asupan vitamin A dengan kepadatan mineral tulang akan tetapi menunjukkan kecenderungan yang negatif. Kecenderungan yang negatif juga dinyatakan oleh McDonald et al 26 bahwa asupan vitamin A berkorelasi negatif dengan kepadatan mineral tulang pada wanita pasca menopause. Penelitian penelitian lainnya juga menyatakan kalau konsumsi vitamin A berkorelasi negatif dengan kepadatan tulang pada wanita pasca menopause. Studi eksperimen pada hewan menunjukkan pentingnya vita min A pada proses remodeling tulang, defisiensi akan men yebabkan pertumbuhan tulang terganggu akan tetapi kelebihan dapat mempercepat resopsi, kerapuhan dan terjadinya fraktur tulang.

Hasil penelitian yang tidak signifikan bisa disebabkan asupan vitamin A pada subyek penelitian sebagian besar $(63,3 \%)$ rendah, absorbsi dan biovailabilitas dari jenis bahan makanan sumber vitamin A, sehingga tidak berpengaruh terhadap kepadatan mineral tulang. Perbedaan hasil penelitian dibandingkan penelitian lain bisa juga disebabkan oleh perbedaan bagian tulang yang diukur kepadatan mineral tulangnya ataupun populasi umur penelitian. Keterbatasan pada penelitian adalah asupan sayur sayuran dihitung jadi satu antara sayuran berwarna hijau dan jenis sayuran lain, 
padahal bioavailabilitas pada sayuran hijau lebih rendah bila dibandingkan yang tidak berwarna hijau maupun sumber vitamin A yang nerasal dari hewani.

Hasil penelitian tidak ada hubungan yang bermakna antara asupan vitamin $\mathrm{C}$ dengan kepadatan mineral tulang yang ditunjukkan oleh nilai $p=0,217$ dan $r=-0,159$. Hasil penelitian sama dengan penelitian Ramayulis 25 pada wanita muda usia 35-40 tahun yang tidak menunjukkan hubungan yang signifikan antara asupan vitamin $C$ dan kepadatan mineral tulang. Kecenderungan yang negatif bisa disebabkan adanya faktor pengganggu yaitu rendahnya asupan vitamin C pada subyek penelitian $(41,7 \%$ asupannya rendah) sehingga tidak mempengaruhi kepadatan mineral tulang pada wanita pre menopause. Fungsi vitamin C membantu absorbsi kalsium dengan menjaga agar kalsium berada dalam bentuk larutan yang mudah diserap, kalau asupan vitamin C rendah maka kalsium sulit diabsorbsi tubuh.

Penelitian Tucker ${ }^{27}$ menyatakan keterkaitan antara vitamin $\mathrm{C}$ dengan kepadatan mineral tulang belum menunjukkan hasil yang konsisten pada wanita pasca menopause. Penyebabnya yaitu adanya hubungan yang komplek antara vitamin $C$ dengan berbagai faktor di antaranya seperti asupan kalsium, penggunaan terapi estrogen dan kebiasaan merokok. Wanita dengan sejarah tidak merokok dan tidak menggunakan estrogen, kadar serum asam askorbat tidak tampak berhubungan dengan rendahnya kepadatan tulang.

Hasil pada penelitian ini tidak ada hubungan yang bermakna antara asupan vitamin D dengan kepadatan mineral tulang yang ditunjukkan oleh nilai $p=0,799$ dan $r=$ 0,034 . Kecenderungan yang positif sejalan dengan penelitian Dawson-hughes ${ }^{28}$ bahwa kombinasi suplementasi kalsium dan vitamin D yang cukup mengurangi kerapuhan tulang. 26 Penelitian lain yang mendukung yaitu penelitian yang dilakukan pada wanita kelompok Nurse's Health Study yang mengonsumsi vitamin D> 12,5 $\mu \mathrm{g}$ memiliki risiko patah tulang panggul $75 \%$ lebih rendah dibandingkan dengan kelompok yang mengonsumsi $<3,5 \mu \mathrm{g}$ per hari ${ }^{29}$. Vitamin $\mathrm{D}$ yang adekuat penting untuk mencegah kerapuhan tulang. Asupan yang rendah sampai dengan sedang, menyebabkan absorbsi kalsium lebih banyak tergantung pada aksi 1,25-dihydroxyvitamin D sebagai transport aktif. Vitamin D yang tidak cukup menyebabkan absorbsi kalsium berkurang, konsentrasi hormon parathyroid tinggi dan rata rata resorpsi tulang meningkat dan pada akhirnya menyebabkan fraktur. Penelitian kasus kontrol menunjukkan bahwa lansia yang mengalami fraktur panggul konsentrasi serum 1,25-dihyd roxy vita min D1,25-dihydroxyvitamin D lebih rendah dibandingkan dengan lansia yang tanpa fraktur ${ }^{30}$. Sejalan dengan pertambahan usia, kapasitas vitamin D mungkin menurun sejalan dengan menurunnya kapasitas kulit untuk menghasilkan cholecalciferol, kemampuan hati atau ginjal untuk hidroksilasi vitamin D menjadi bentuk aktif menurun atau rendahnya konsumsi makanan yang berasal dari susu atau gannguan absorbsi vitamin D di usus ${ }^{31} 32$. Hubungan yang tidak signifikan pada penelitian ini dapat disebabkan oleh asupan kalsium dan vitamin D yang tidak adekuat (63,3\% asupannya kurang) sehingga mengurangi absorbsi kalsium dan peningkatan konsentrasi serum hormon parathyroid.

Hasil pada penelitian ini tidak ada hubungan yang bermakna antara asupan vitamin kalsium dengan kepadatan mineral tulang yang ditunjukkan oleh nilai $p=0,115$ dan $r=0,206$. Hasil penelitian sejalan dengan penelitian Mazes \& Barden (1991), Nurchasanah 19 dan Ramayulis 25 bahwa tidak ada korelasi antara asupan kalsium dan kepadatan mineral tulang. Tidak adanya hubungan bisa disebabkan oleh sebagian besar subyek penelitian asupan kalsiumnya kurang $(96,7 \%)$ dan absorbsinya yang mulai berkurang pada wanita premenopause. Wimalawansa ${ }^{14}$ juga menyatakan homeostais kalsium negatif disebabkan oleh kurangnya asupan makanan, bioavailabilitas dari bahan makanan, penyerapan yang lemah atau pengeluaran yang berlebihan mengakibatkan kehilangan kalsium dari tulang dan selanjutnya akan meningkatkan patah tulang.

Kalsium hanya bisa diabsorbsi bila terdapat dalam bentuk larut air dan tidak mengendap karena unsur makanan lain seperti oksalat, fitat, asam lemak atau fosfat yang berlebihan. Asupan fosfor pada penelitian ini sebagian besar $(61,7 \%)$ termasuk dalam kategori lebih. Hasil penelitian yang tidak signifikan bisa disebabkan karena faktor absorbsi kalsium yang kurang akibat asupan fosfor yang berlebihan. Proses pembongkaran tulang oleh osteoklas akan berlangsung lebih lama sehingga tulang lebih cepat menjadi keropos dan mudah patah (osteoporosis) apabila ketersediaan kalsium tidak cukup. 
Hasil penelitian tidak ada hubungan yang bermakna antara asupan Fosfor dengan kepadatan mineral tulang yang ditunjukkan oleh nilai $p=0,463$ dan $r=0,097$. Hasil penelitian sa ma dengan penelitian Ramayulis 25 dengan subyek penelitian wanita umur 35-40 tahun, bahwa tidak ada hubungan antara asupan fosfor dan kepadatan mineral tulang. Kecenderungan yang positif sejalan dengan penelitian Illich \& Kersketter (2000) serta Nurchasanah ${ }^{19}$.

Hubungan yang cenderung positif bisa disebabkan oleh nilai rasio $\mathrm{Ca}: \mathrm{P}$ yang lebih tinggi ( $0,5 \mathrm{Ca}: \mathrm{P})$ dari penelitian sebelumnya $(0,25$ $\mathrm{Ca}: \mathrm{P}$ ). (Anderson 1999) dan penelitian Nurchasanah ${ }^{19}$ rasio Ca:P hampir sama dengan penelitian ini yaitu 0,58 . Asupan fosfor dari subyek penelitian sebagian besar $(61,7 \%)$ dalam kategori lebih. Asupan fosfor yang berlebihan dapat mengubah rasio Ca:P, khususnya jika asupan kalsium juga rendah (asupan kalsium subyek peneltian sebagian besar juga rendah). Keadaan ini akan merangsang sekresi hormon parathyroid yang berakibat pada pengeroposan tulang. Jenis bahan makanan sumber fosfor yang sering dikonsumsi subyek penelitian ikan, ayam dan serealia.

Hasil penelitian tidak ada hubungan yang bermakna antara asupan zat besi dengan kepadatan mineral tulang yang ditunjukkan oleh nilai $p=0,932$ dan $r=0,012$. Hasil penelitian tidak sama dengan dengan penelitian Maurer et al 34, Harris $^{35}$ serta Nurchasanah ${ }^{19}$ akan tetapi sama sama menunjukkan kecenderungan yang positif. Hubungan yang cenderung positif karena zat besi sangat esensial untuk sintesis kolagen yang merupakan tempat terjadinya mineralisasi tulang. Zat besi juga terlibat dalam konversi 25-hidroksi vitamin D menjadi 1,25 dihidroksi vitamin $\mathrm{D}$ yang merupakan bentuk aktif dari vitamin D. Vitamin D dibutuhkan untuk pengaturan kalsium dan fosfor secara tepat. Jadi secara tidak langsung zat besi turut berperan dalam proses mineralisasi tulang. 34,35

Hasil penelitian yang tidak signifikan bisa disebabkan oleh kemampuan absorbsi dan juga biovailabilitasnya dalam usus. Pada penelitian ini tidak dibedakan zat besi yang berasal dari protein hewani maupun nabati. Zat besi yang berasal dari hewani akan lebih mudah diserap (30\%) oleh usus dibandingkan dengan zat besi yang berasal dari pangan nabati $(5 \%)^{36}$. Bahan makanan sumber zat besi yang sering dikonsumsi oleh subyek penelitian adalah ayam, ikan, kedelai, tempe, tahu dan sayuran berwarna hijau.
Usia perta ma kali menstruasi pada subyek penelitian menunjukkan tidak ada hubungan yang signifikan dengan nilai $p=0,228$ dan nilai $r=-0,158$. Penelitian sejalan dengan peneltian Osei-Hyiaman et al37 yang menyatakan bahwa umur pertama kali menstruasi memiliki hubungan negatif pada wanita pasca menopause di Turki. Penelitian Nurchasanah ${ }^{19}$ hasilnya sama yaitu tidak bermakna tapi ada kecenderungan hubungan negatif. Penelitian lain yang hasilnya sama yaitu Unni et al ${ }^{18}$ di India pada wanita di atas usia 40 tahun. Penelitian Unni pada 43 wanita yang terlambat menstruasi ( $>16$ tahun) sebanyak $48,8 \%$ mempunyai kepadatan mineral tulang yang normal pada spine dan 16,3\% tergolong osteoporosis.

Davis et al38 menyatakan bahwa usia pertama menstruasi merupakan salah satu faktor yang mempengaruhi pencapaian massa tulang puncak pada wanita pre menopause multi etnis yang tinggal di hawai.36 Ito et al 39 menyatakan bahwa menstruasi dini berkaitan dengan kepadatan mineral tulang yang tinggi dan salah satu faktor yang berpengaruh terhadap pencapaian massa tulang puncak. Pubertal spurt yang terjadi dua tahun setelah menstruasi yang pertama menjadi faktor yang diduga ikut berpengaruh dan pada masa itu terjadi akumulasi dalam tulang. Unni (2010) menarche dini berhubungan dengan massa tulang yang lebih tinggi sebab tulang lebih awal terpapar estrogen selama beberapa tahun lebih awal

Menarche diduga berpengaruh menstimulasi perkembangan tulang dengan cara meningkatkan aktifitas osteoblast yang dibarengi dengan aktifnya hormone estrogen pada system endokrin remaja putri .

Hasil penelitian menunjukkan bahwa paritas tidak berhubungan dengan kepadatan mineral tulang yang ditunjukkan dengan nilai $p=0,563$ dan $r=-0,076$. Hasil penelitian osdemir et al ${ }^{41}$ menyatakan ada korelasi negatif antara jumlah paritas dengan kepadatan mineral tulang. Paritas juga berpengaruh pada massa tulang puncak dan kerapuhan tulang.

Usia perta ma kali hamil tidak berhubungan dengan kepadatan mineral tulang yang ditunjukkan dengan nilai $p=0,277$ dan $r=0,143$. Sower ${ }^{9}$ menyatakan kehamilan pada umur yang lebih muda, antara ibu dan skeleton janin keduanya sama sama menuju proses mature sehingga berakibat densitas tulang yang lebih rendah dan meningkatkan resiko kehilangan kepadatan tulang ketika peri menopause. Sela ma kehamilan sekitar 25 - 30 gr kalsium (2-3\% dari 
total kalsium tubuh) ditransfer dari ibu ke janin. Selama hamil absorbsi kalsium di saluran cerna meningkat $50 \%$ sebagai akibat peningkatan level 1,25 dihydroxy-vitamin $\mathrm{D}$ dan level estrogen pada sirkulasi maternal menjadi tinggi. Hormon parathyroid juga meningkat selama hamil dan menyebabkan mobilisasi kalsium dari skeleton.

Lama menyusui tidak berhubungan dengan kepadatan mineral tulang yang ditunjukkan dengan nilai $p=0,639$ dan $r=0,062$. Hasil penelitian ini sama dengan penelitian Unni ${ }^{18}$ bahwa tidak ada hubungan yang signifikan antara lama menyusui dengan prevalensi osteoporosis. Pemberian ASI dapat menyebabkan adanya stress pada metabolism kalsium dan berakibat pada metabolism tulang. Durasi dan frekuensi menyusui merupakan faktor yang mempengaruhi BMD dan metabolisme tulang. Menyusui dalam jangka panjang dihubungkan dengan meningkatnya kehilangan massa tulang. Beberapa penelitian melaporkan hasil yang bervariasi 40 (Osdemir 2005). Sebuah studi prospektif oleh Laskey et al42 menemukan bahwa menyusui berhubungan dengan penurunan massa tulang adalah sementara dan akan kembali bila menyusui frekunsinya menurun atau berhenti dan wanita yang melahirkan bayi sebanyak 5 kali atau lebih mempunyai total lama menyusui yang lebih lama disbanding wanita yang melahirkan 1-2 ataupun 3-4. Selama kehamilan dan menyusui terjadi perubahan pada metabolisme tulang dan keduanya merupakan faktor resiko rendahnya kepadatan mineral tulang.

Penelitian ini terdapat beberapa keterbatasan di antaranya pengukuran asupan dilakukan dengan menggunakan kuesioner frekuensi pangan (FFQ) semi kuantitatif. Hasilnya dipengaruhi oleh daya ingat subyek penelitian sehingga bisa kekurangan atau kelebihan. Alat yang digunakan untuk mengukur kepadatan mineral tulang adalah Quantitatif Ultrasound bone densitometri yang hanya bisa memprediksi besarnya kepadatan tulang tanpa menunjukkan letak tempat terjadinya pengeroposan tulang. Aktifitas fisik yang berpengaruh terhadap kepadatan mineral tulang tidak diukur pada penelitian ini.

\section{Simpulan dan Saran}

Berdasarkan hasil penelitian dapat diketahui bahwa umur dengan kepadatan mineral tulang ada hubungan negatif yang signifikan. IMT, asupan zat gizi dan riwayat reproduksi tidak berhubungan dengan kepadatan mineral tulang. Hasil penelitian yang berbeda dengan teori bisa disebabkan asupan sebagian besar zat gizi rendah. Kemungkinan hasilnya akan berbeda bila dilakukan di tempat yang sosial ekonominya lebih tinggi dibandingkan dengan di wilayah kecamatan Genuk.

Bagi peneliti lain yang tertarik dengan penelitian tentang kepadatan mineral tulang bisa menambah analisis dengan parameter biokimia yang berhubungan dengan remodeling tulang dan status biokimia gizi sehingga pengaruh asupan zat gizi terhadap kepadatan mineral tulang bisa dibuktikan dengan akurasi yang lebih tinggi. Selain itu menambah pengukuran antropometri selain IMT seperti lean body mass, free fat mass dan lainnya. Aktifitas fisik yang berpengaruh terhadap kepadatan mineral tulang perlu juga ditambahkan. Bagi masyarakat khususnya subyek penelitian supaya asupan zat gizi bisa dipenuhi dalam konsumsi sehari hari dalam jumlah yang cukup sesuai Angka Kecukupan Gizi yang dianjurkan sehingga ketika wanita memasuki masa menopause, kejadian osteoporosis dan fraktur tulang bisa diminimalkan. Ikan sebagai salah satu protein hewani yang banyak terdapat di wilayah kecamatan Genuk bisa dijadikan sebagai sumber protein hewani yang murah, tinggi kalsium, rendah kolesterol yang baik untuk wanita pre menopause, menopause dan kelompok usia lainnya.

Faktor riwayat reproduksi juga bisa dimodifikasi dengan cara tidak hamil di usia yang terlalu muda, tidak mempunyai banyak anak sehingga ketika wanita memasuki menopause, kejadian osteoporosis dan fraktur tulang bisa diminimalkan..

\section{Ucapan Terima Kasih}

Terima kasih disampaikan kepada Poltekkes Kemenkes Semarang yang telah mendanai keberlangsungan jurnal ini. Atau ucapan terima kasih terutama ditujukan kepada pemberi dana penelitian atau donatur. Ucapan terima kasih dapat juga disampaikan kepada pihak-pihak yang membantu pelaksanaan penelitian. 


\section{Daftar Pustaka}

1.Haines CJ, Ludicke. 1997. Contraception in the perimenopause. First consensus meeting in the East Asian Region, Geneva.

2.Anderson JB. 2000. Nutrition for bone health. In : Mahan LK, Stump SE (Ed) Krause's : Food, Nutrition and Diet Therapy. WB Saunders Company. Philadelphia, Pennsylvania.

3.National Osteoporosis Foundation (NOF). 2005. A debilitating disease that can be prevented and treated.

4.Rahman IA, Setyohadi B, Kusumawijaya K, et al. 2005. Penggunaan bone densitometry pada osteoporosis. HTA Indonesia 2005; 26- 27

5.Prihatini S, Mahirawati VK, Jahari AB et al. 2009. Faktor determinan risiko osteoporosis di tiga propinsi di Indonesia, LIPI

6.Tucker KL, Hannan MT, Chen H et al. 1999. Potassium, magnesium and fruit and vegetable intake are associated with greather bone mineral density in elderly men and woman. Am J Clin Nutr ; (77) : 10-11

7.Tucker KL, Chen H, Hannan MT, et al. 2002. Bone mineral density and dietary patterns in older adults : the Framingham osteoporosis study. Am J Clin Nutr; 76 : 245-252

8.. Osdemir F, Demirbag D \& Rodoplu M. 2005. Reproductive factors affecting the bone mineral density in post menopausal woman Tohoku J Exp Med ; (205) : 277-285

9.Sower MF. 2001. Premenopausal reproductive and hormonal characteristic and the risk for osteoporosis In : Marcus R, Feldman D, Kelsey J (eds) Osteoporosis Ed 2nd Academic Press, San Diego ; 1):721- 739

10.Jordan KM \& Cooper C. 2002. The epidemiology of osteoporosis. Clin Rheumatol 16; (5): 795-806

11.Lane NE. 2001. Lebih lengkap tentang : Osteoporosis, petunjuk untuk penderita dan langkah langkah penggunaan bagi keluarga. PT Raja Grafindo, Jakarta.

12.Whitney EN, Sizer FS. 2000. Nutrition Concept and Controversies. Wadsworth Thompson Learning, USA.

13.Sellmeyer DE, Stone KL, Sebastian A, et al. 2001. A high ratio of dietary animal to vegetable protein increases the rate of loss and the risk of fracture in postmenopausal woman. Am J Clin Nutr (72): 118-122
14.Wimalawansa SJ. 2004. Relationships of calcium, vitamin $D$ and other nutrient to bone health. Business briefing : Women's health care : $1-11$

15.Peterkofs ky B. 1991. Ascorbate requirement for hidroxylationand secretion of procollagen : synthesis in scurvy Am J Clin Nutr ; (54) 1135S-1140S

16.Calvo MS, Kumar R, Heath H. 1988. Elevated secretion and action of serum parathyroid hormone in young adults consuming high phosphorus, low calcium diets assembled from common foods. J Clin Endocrinol Metab ; (66): 823-829.

17. Mulyono. 1999. Kandungan mineral tulang pada sampel wanita pascamenopause Indonesia di Jakarta: pengukuran dengan menggunakan Dual Energy X-Ray Absorptiometry. Tesis, Program Studi Ilmu kedokteran Olah Raga Fakultas Kedokteran, Universitas Indonesia, Jakart.

18.Unni J, Garg R, Pawar R. 2010. Bone mineral density in women above 40 years. J Midlife health $1 ;(1): 19-22$

19.Nurchasanah. 2006. Faktor-faktor yang berhubungan dengan kepadatan mineral tulang pada wanita pasca menopause. Tesis. Magister, Institut Pertanian Bogor;

20.Kosnayani AS. 2007. Hubungan asupan kalsium, aktifitas fisik, paritas, Indeks Massa Tubuh dan kepadatan tulang pada wanita pasca menapouse. Tesis, Magister, Universitas Diponegoro, Semarang.

21.Morin S, Tsang JF, Leslie WD. 2009. Weight and body mass index predict bone mineral density and fractures in women aged 40 to 59 years. Osteoporos Int (20) : 363-370

22.Kameda T, Mano H, Yuasa T et al. 1997. Estrogen inhibits bone resorption by directly inducing apoptosis of the bone-resorbing osteoclasts. J Exp Med (186) : 489-495

23.Kerstetter JE, O’Brien KO \& Insogna KL. 2003. Dietary protein, calcium metabolism and skeletal homeostasis revisited. Am J Clin Nutr (78):584S-92S

24.Mazess RB, Barden HS. 1991. Bone density in premenopausal women: effects of age, dietary intake, physical activity, smoking, and birthcontrol pills. Am J Clin Nutr (53) :132-42.

25.Ramayulis R. 2008. Hubungan fosfor dengan asupan vitamin, mineral dan rasio asupan kalsium dan fosfor dengan kepadatan mineral tulang kalkaneus wanita Tesis. Magister Universitas Gajahmada Yogyakarta

26. Macdonald HM, New SA, Golden MHN et al. 
2004. Nutritional association with bone loss during the menopausal transition: evidence of a beneficial effect of calcium, alcohol and fruit and vegetable nutrients and of a detrimental effect of fatty acids. Am J Clin Nutr (79) : 155-165

27.Tucker KL. 2003. Dietary intake and bone status with aging Current Pharmaceutical Design. Am J Clin Nutr (9) : 301-340

28.Dawson-Hughes B, Harris SS, Krall EA, Dallal GE. 1997. Effect of calcium and vitamin D supplementation on bone density in men and women 65 years of age or older. N Engl J Med (337) : 670-676.

29.Feskanich D, Willet WC, Colditz GA. 2003. Calcium, vitamin $D$, milk consumption, and hip fractures : a prospective study among postmenopausal women. Am J Clin Nutr; (77) : 504-511.

30.Weatherall M. 2000. A meta-analysis of 25-hydroxyvitamin $D$ in older people with fracture of the proximal femur. N Z Med J (113): 137-40.

31.MacLaughlin J, Holick MF. 1985. Aging decreases the capacity of human skin to produce vitamin D3. J Clin Invest (76) : 1536-1538.

32.Tsai KS, Health H, Kumar R, Riggs BL. 1984. Impaired vitamin $D$ metabolism with aging in women: possible role in pathogenesis of senile osteoporosis. J Clin Invest (73) :1668-72. 